\title{
Sustainable Entrepreneurship and Sustainable Development in Nigeria: Prospects and Challenges
}

\author{
Adijat Olubukola OLATEJU ${ }^{1 *}$, Rasaq Akonji DANMOLA², Abubakar Wambai AMINU ${ }^{3}$ \\ ${ }^{1,2}$ Faculty of Social Sciences, Department of Economics, Lagos State University, Ojo, Lagos, Nigeria. \\ ${ }^{3}$ Faculty of Social Sciences, Department of Economics, Bayero University Kano, Kano State, Nigeria \\ *Corresponding Author
}

\begin{abstract}
Entrepreneurship development is not a new tool for poverty reduction across the globe. However, with the recent awareness of the need to make the environment healthy for people, planet, and bio diversity, the need for sustainable entrepreneurship has been in the limelight. For sustainability to be achieved in terms of economic, social and environment, entrepreneurs both in developed and developing countries have been encouraged on the need to go green in their business activities. However, in most developing countries like Nigeria, the awareness is low. In view of this, this study focuses on this grey area of research by conceptualizing what sustainable entrepreneurship is all about. Specifically, the study explains the concept of sustainable development and sustainable entrepreneurship, examines the prospects in sustainable entrepreneurship, and identifies some challenges that could be encountered when entrepreneurs embarked on sustainable entrepreneurship. This will help to create awareness for both existing entrepreneurs and new entrepreneurs on the need to go green in their business activities, which will eventually help to safeguard people and the environment from environmental issues such as pollution and degradation and at the same time enhances profitability.
\end{abstract}

Key words: Entrepreneurship, , green, Sustainable Development, pollution, degradation

\section{INTRODUCTION}

$\mathrm{R}^{\mathrm{s}}$ esources are not equitably distributed by nature, in view of this, protecting resources and planet is germane in order to ensure inclusive growth and sustainable development. To achieve this, countries are advised at the United Nation conferencesand eventson environmentsto embark on green economy which would help to ensurea resource efficient economy.

The recent united Nation conference in 2019 on environmental issues where world leaders emerge and consideredgreen economy in the context of sustainable developmentin solving environmental issues and poverty alleviation. In this regards, businesses are encouraged to be mindful of their business activities, and to generate decent jobs, through energy efficient technologies and industrial process. This led to a new form of entrepreneurship known as sustainable entrepreneurship. Hitherto, the major concern of many businesses is to earn profit which is the economic concern, however, the recent advocate for green economy has brought a lot of concern for entrepreneurs on the need not to only focus on profit earning, but also to preserve their environment.

Sustainable entrepreneurship is when the conventional business practice is combined with environmental awareness. This entails the entrepreneur's mind of not only making profit, but also adding positively to the environment through their business activities. Sustainable entrepreneurship will help to have a pollution free environment, maintain a healthy life style, protect the ecosystem, biodiversity, and ensure a sustainable environment for the current and future generation.

However, the increase awareness on environmental issues such as pollution, environmental degradation, loss of biodiversity has brought about interest in the area of sustainable entrepreneurship so that inclusive and sustainable development can be achieved. Thebrundtland report of 1987 and other UN events on environmental sustainability have brought about increase awareness among countries on the need to preserve their environment. Similarly, in Nigeria, the high level of carbon dioxide and other greenhouse gases released from various business activities, have necessitated the need for the country to focus more on green economy, in order to reduce the negative effect of these pollutants on human and the environment. Consequently, in Nigeriafocus has been placed on sustainable business as a means to enhance sustainable development. However, the level of awareness of this new research area is not widely spread among entrepreneur in the country. Also, research in this area is scarce especially among entrepreneurs who are the drivers of most economy activities most especially in developing countries.To addto other research works in the area of sustainable entrepreneurship especially in developing country like Nigeria where the importance of entrepreneur to the economy cannot be overemphasized, therefore, the objectives of this study are to presents a conceptual paper on sustainable entrepreneurship, identify some sustainable businesses within the Nigeria context and some prospects and challenges in sustainable entrepreneurship.

After the introduction, the second part of the paper is on the concept of entrepreneurship, sustainable entrepreneurship, and sustainable development. The third part deals with some sustainable businesses that entrepreneur can operate within the Nigeria context. The forth part of the paper identify some prospects and challenges in sustainable entrepreneurship. the 
final part of the paper concludes and gives some recommendations.

\section{THE CONCEPT OF ENTREPRENEURSHIP, SUSTAINABLE ENTREPRENEURSHIP, AND SUSTAINABLE DEVELOPMENT}

\section{Entrepreneurship}

To a layman, Entrepreneurship is the process and procedure of combining and converting other factors of production into a finish product. The concept entrepreneurship is a multidimensional concept, and finding a clear definition may be difficult when defining entrepreneur. (Schaper, 2002), Carsrud \& brannback, 2007, Gatner, 1989,). Oluremigbenga (2011) emphasized the merit of entrepreneurship to economic growth in the area of employment generation and the empowerment of the poor. It is the concept of developing and managing business venture taking risks with the target to make profit. In the academic area, entrepreneurship is the study of how new businesses are created and managed. Entrepreneurship is identified as the heart of a nation economy. Entrepreneurship has also been seen as the wheel of an economy by enhancing economic growth, technology advancement, and innovation (Geverenova, 2015)

Udih and Odibo, (2016) explained that growth in entrepreneurship could enhance economic development through job creation as a result of increase in the number of MSMEs. One of the earliest definition of entrepreneurship is by Schumpeter (1934) who defines entrepreneurship as an innovation price of creative destruction. In the world of Majid Latif and Koe (2017) entrepreneurship is defined as "a process of identifying, evaluating and pursuing opportunities through creative, innovative and transformation to produce new products, processes and values that are beneficial".

Entrepreneurship also refers to as the process of creating a new business venture (Gibbs, 2009) while some scholars see entrepreneurship process at not confirmed to new business, though cninclude the creation of new business (Shane and Venkataraman ,2000). In line with his authors like Greco \& De Jong (2017, have identified the importance and different function of new and existing business indeveloping the society. This authors defines entrepreneurship as "the process that strives for innovation and or value creation and capture through opportunity spotting and development, implying a more or less high degree of risk taking due to its intrinsic uncertainty

One of the most acceptable definition of entrepreneurship is based on Kirzner (1973) who defined entrepreneurship as mainly the process by which opportunities are discovered, evaluated and exploited. Some scholars believe that business opportunity are created while others believe that opportunity are discovered but can be created through their action and interaction. (Bruvat and Julien 2000; Dimov, 2007; Sarason et al.; 2006; Archichvili et al., 2003; Mc Mullen and Shepherd, 2006; Van de Ven, 1993). New opportunities are believed to be discovered by exploring the external environment (Dimon2007)

\section{The concept of Sustainable Entrepreneurship}

The quest for environmental sustainability which is part of sustainable development has necessitated the need to have a green economy and for green economy to be attained it means some aspects of the economy need to be altered. Entrepreneurship is an important aspect of economy especially in developing country, that would be affected by this new trend in economy- green economy.

As a result of environmental degradation and harmful pollutant emitted into the environment which often affect ecosystem and biodiversity. The United Nation in its conferences and events on environmental issue emphasized on the need for country to be conscious about their environment through green economy. One of the major source of achieving this is through sustainable entrepreneurship.

Therefore, sustainable entrepreneurship emanated as a result of the need for business enterprise to be environmental conscious as a result of environmental degradation and harmful pollutants emitted into the environment that often affect ecosystem and biodiversity. There are different definitions of sustainable entrepreneurship; the world was coined out of the need to ensure sustainable development. It involves the act of operating business with the aim of not only making profit but also contributing positively to the environment and the people. Therefore, sustainable entrepreneurship fulfils not only economic needs, but also social and environmental needs. Unlike conventional/traditional entrepreneurship that is based on economic needs (profit)

Lenczuk (2017) identifies two types of entrepreneurship in the literature- traditional and conventional entrepreneurship/commercial entrepreneurship.While Young \& Tilley (2000) identified 3 types of entrepreneurship environment, social, and economic entrepreneurship which the authors refer to as the root of different kinds of entrepreneurship.

Venkataraman (1997) defined sustainable entrepreneurship as an area that seeks to understand howopportunities that can help to bring into existence future goods and services are discovered, created, and exploited by whom, and with what consequences. In this definition the author emphasized that the consequence of entrepreneurship can emanate from economic, psychological, and social in nature. However, Gast et al., (2017) defined sustainable entrepreneurship as the procedure of pinpointing, assessing, and grapping opportunities that reduce a business activities effect on the natural environment and create benefit for the entire society and local environment.

Sustainable entrepreneurship is a business activity that maximizes economic gains (profit) social gains, environmental gains while minimizing or preventing 
economic cost, social cost, and environmental cost in the society. Sendawula, Turyakira \& Alioni (2018) defined sustainable entrepreneur as the combination of sustainable development with entrepreneurship. Thus, sustainable entrepreneurship is more encompassing than the conventional entrepreneurship.

Sustainable Entrepreneurship is when entrepreneurial opportunities are identified, created and utilized to ensure sustainability in terms of social and environmental benefit for others in the society (Shepherd and Patzelt, 2011). Cohen and Winn (2007) emphasized that opportunity can be identified out of market imperfection, inefficiency in the activities of the firm, presence of externalities, imperfect price mechanism, and information asymmetric.

A unique definition of sustainable entrepreneurship was suggested by Iyigun (2015) that sustainable entrepreneurship is in between for profit and not for profit "in between cash and cause. According to the author, prosperity in business activity is the primary aim of sustainable entrepreneurs. The author believes that the aim of entrepreneurs is to prosper in their business activities, thus this can emanate in the form of monetary value or non-monetary value

Greco\&De Jong (2017) referred sustainable entrepreneurshipas the creation of value that is useful for the community which emanates from the creation of opportunity and development in an uncertain environment. This involves the risk which entrepreneurs need to take in business.

Belzand Binder (2017), defined sustainable entrepreneurship as entrepreneurship that encompasses conventional entrepreneurship, environmental entrepreneurship, and social entrepreneurship. The author explained further by making distinction on these types of entrepreneurship that conventional form of entrepreneurship is a one dimensional form of entrepreneurship that is based on achieving only economic gains while environment and social entrepreneurship are two dimensional form of entrepreneurship that focus on economic with ecological gains, and social with financial gains respectively.

Sustainable Entrepreneurship is the creation of value that is useful for the community which emanates from the creation of opportunity and development in an uncertain environment. This involves the risk which entrepreneurs need to take in businessGreco\& Jong (2017). Sendawula, Turyakira \&Alioni (2018) defines sustainable entrepreneurship as the combination of sustainable development with entrepreneurship.

\section{Sustainable Development as a concept}

The quest to promote equitable distribution of resources and ensure inclusive benefit in economic growth necessitate the need for Sustainable Development. Aside from poverty alleviation sustainable development is another area of development that policy makers focus on especially in developing countries.
This term was initiated in 1987 by Freer Sparckley and expatiated in details ten years after in 1997by John Elkington. According to Elkington (1997), Sustainable Development encompasses the three bottom lines - people, place, and planet which is also called 3Ps. The awareness of TBL enables corporation to put attention not only on economic gains but also enable them to be mindful about their environmental and social advantages and disadvantage that may be put in or eliminate from society respectively. The concept was defined clearly in the Brundtland's commission Report of the Un in 1987 as "development that meets the needs of the presents without compromising the ability of future generation to meet their own needs" (WCED, 1987). Sustainable Development encompasses three dimensions known as the 3Ps or triple bottom line (TBL). The concept sustainable development has gained wider attention since the Brundtland report on our common future in 1987.

Sequel to this report, many definitions have emerged from various scholars and international organization on the concept of sustainable development. And many proactive actions have been taken and still being recommended by various international organisations on environment, NGOs, and government in ensuring sustainable development. For instance, to Lotfi, Yousefi \& Safari, (2018) sustainable development is defined as a continuous development that is above economic development. This means that Sustainable Development encompasses economic development and other development dimensions The authors also defined sustainable development as that development which involves economic and social development in a manner that does not jeopardized the entire natural resources of the society, and maintaining and augmenting the quality of life of individuals, animals, plants and non-living things within the ecosystem. Sustainable development helps to prevent, eliminate, or the demolition of natural resources, degradation of the environment, climate, ozone layer depletion and maintenance of good quality life style for the present and future generation.

Kushiwah (2010), defined sustainable development as a situation where resource, investment, technology advancement, and institutional changes are utilized in agreement with the requirement of the current and succeeding generation. The satisfaction of the parties involve is also seen as a means to ensure sustainable development. For instance, a company is said to be sustainable when it is able to earn profit for its stakeholders, protect the environment and ensure a healthy lifestyle for all the stakeholders (Savitz and Weber, 2006). Therefore, sustainable development is a development that ensures equality and fair play in the society.

Given that sustainable development compasses economic, environmental and social objectives across sectors, territories and generation. This implies that sustainable development entails no division in terms of environmental, social, and economic in decision making process in order to achieve development that will be sustained (Emas ,2015). 
Sustainable entrepreneurship can pave way for business opportunities. (Moshina, 2015; Dean \& Mc mulloen, 2007; Pacheco, 2010; Cohen and Winn, 2007). Sustainable business can help the economy by booting it during period of recession and fall GDP growth since conventional ways in enhancing economy recovery are less effective (UNEP, the business case for green economy).

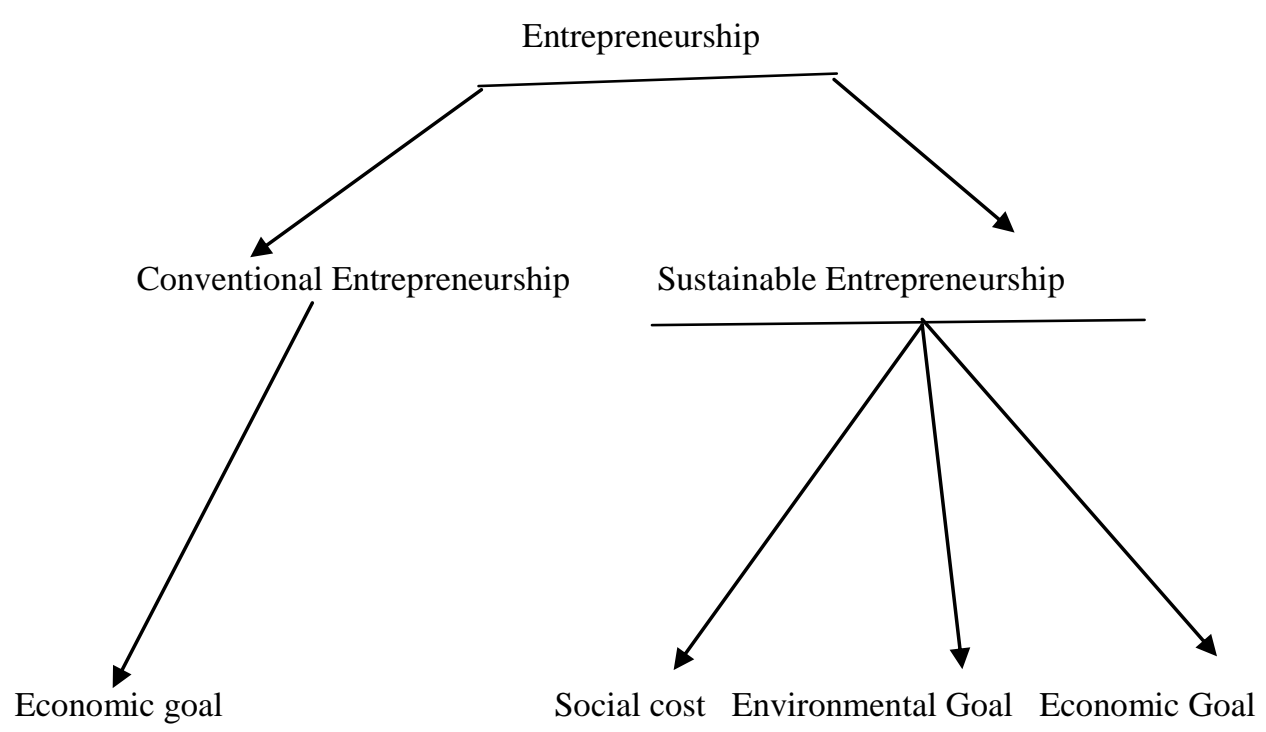

The concept of Entrepreneurship

\section{SOME SUSTAINABLE BUSINESS FOR ENTREPRENEUR IN NIGERIA}

There are many business opportunities for entrepreneur that wants to practice sustainable entrepreneurship in Nigeria. The following are some of the business opportunities that sustainable entrepreneur can venture into within the Nigeria context:

\section{1) Lawns business/Landscaping Business:}

Unlike before, nowadays, planting of flower has been a viable business where entrepreneur can venture in. This business usually requires less capital and the business will not only earn profit for entrepreneurs but also help to beautify and save the environment. This kind of business involves maintenance of grass to the level that will befit the environment. An entrepreneur can venture in to this business as the cost of starting and operating the business is usually very small as entrepreneur can purchase new or fairly used lawn machine. This will help to save the ecosystem, beautify the environment, and thus earn profit for entrepreneur.

\section{2) Sale of Energy Saving product:}

In a developing country like Nigeria where there is in appropriation in energy prices this could make energy intensity to be high while energy efficient will be low. The high energy intensity and low energy efficiency means the rate of energy consumption will be high thereby affecting the environment through carbon dioxide emitted from some of the fossil fuel. To prevent this, an entrepreneur can come in the area of setting up a business that deals with installation of solar system, inverter or may involve in the sale of energy saving bulbs and equipment that use less of energy, thereby reducing carbon dioxide emitted into the environment.

\section{3) Cleaning Product:}

Entrepreneur can focus on the production of ecofriendly cleaning product for household use and also for official use. This kind of cleaning product can be produced with natural ingredients or organic ingredients or ingredients that use small or no chemicals in the production. Given the awareness of customers in organic products and some health hazard involve in the use of some cleaning products, most consumers will prefer cleaning product that uses less or no chemical that are naturally made. This kind of ecofriendly cleaning product will enable an entrepreneur to capture the market in the midst of competitors.

\section{4) Sales of Organic Foods}

Recently, many people are aware of the health hazards of consuming some chemically process foods such as canned food, raw food stuffs, vegetables, and fruits which can arise during the process of production, planting,or during their preservation entrepreneur may focus on sales of organic foods - vegetables and fruits. As People are now aware of the importance of eating more vegetables and fruit in their diet, however, despite this awareness people are also mindful about the chemicals (pesticide and fertilizers) that are often use in producing and preserving the product. In view of this, entrepreneur focusing on the sale of organic food, will be able 
to attract more customers, and as such will increase sales, earn more profit and at the same time ensure a healthy lifestyle for their customers and the environment.

\section{5) Green Consulting}

Another good area an entrepreneur can delve into is in the area of green consulting business. Since awareness and practice of green business is low, an entrepreneur can be a green consultant by giving advice, mentoring, coaching, training, seminars and workshops on how to operate green business.

Information is key and most people are not aware of green business especially in developing countries like Nigeria. As a green business consultant an entrepreneur could make huge impact on the environment and money through the provision of green business consultancy services.

\section{6) Organic Catering}

Since humans are now mindful of the food they eat, operating an organic catering services is another environmental friendly business that an entrepreneur could engage in. This involves sourcing of all ingredients use in the process of catering to be locally produced and organic. Being an organic caterer will make an entrepreneur to be unique among other conventional caterers in the provision of the service.

\section{7) Recycling Business}

Recycling business is another business venture that an entrepreneur could venture into. This business involves the passing of used product for another use. Recycling of used items is not only good for the environment (via reduction in environmental wastes) but it is also helpful in saving cost since the cost of new items are often more expensive than fairly used ones (some items that can be recycle are used clothes, furniture, plastic, books, etc.). The capital requires for establishing a recycling business is also very low and a lot of profit can be earned in the business.

8) Ink refilling Business.

Many people often find it difficult to refill their cartridge when they run out of ink because of the cost involves. Entrepreneur could establish an ink refilling outlet where used cartridge can be refilled. This will save customers the high cost of buying new cartridge and also helps to prevent environmental degradation that may arise from the dumping of used cartridge.

\section{9) Public Toilet}

Social amenities like public toilet are not often found in developing countries like Nigeria. Running an environmentally public toilet/mobile toilet is another business opportunities and also an avenue to achieve sustainability in the area of people, place and planet. This kind of business will not only make the environment clean but also ensure that waste from the toilet are used as by-product for fertilizers and biogas.

\section{Prospects in Sustainable Entrepreneurship}

Sustainable Entrepreneurship arises out of the need to conquer environmental degradation, pollution, and to improve the wellbeing of people in the environment. In view of this, many prospects can be derived from sustainable entrepreneurship. Some of these prospects are highlighted below.

- The business is ecofriendly as carbon dioxide and other pollutants emitted into the environment will be prevented or reduced

- It is cost efficient as it entails recycling of some byproduct and waste product.

- The uniqueness of the product for example, organic productmay enable entrepreneur to have large market share

- It is observed that sustainable entrepreneurs are able to add environmental gains to their profit making unlike the conventional entrepreneurs whose only gain is profit. Therefore, sustainable entrepreneur considers the progress of the environment in relation to profit.

- Sustainable entrepreneur may be able to identifying business opportunities, that could eventually lead to the creation of new ideas and innovation. This will enable entrepreneur to stand firm in the presence of competitors.

\section{Challenges in Sustainable Entrepreneurship}

- Cultural and structural barriers. Structural barriers stem from policies, and regulation/law. It could also emanate from market and financial issues, Cultural barrier on the other hand, entails behavioral and social issues from customers and stakeholders.

- $\quad$ Barriers to sustainable business are also categories by Sandbery\&Aarikka- Stenroos, (2014) into internal and external barriers. Internal barriers according to the authors can arise from the people at the top in the company, personal believes, human factors, external factors which come from the environment (e.g. altitude of competitors, customers and government.

- Cost can be an issue as changing from the conventional entrepreneurship to the environmental entrepreneurship may require some cost attach.

- Awareness among customers and entrepreneurs about green product is low

- Adjusting from conventional entrepreneurship to sustainable entrepreneurship may be challenging for entrepreneurs especially for a new entrepreneur as training may be require in some cases.

- Green human resources may be required for sustainable business to be effective 


\section{CONCLUSION}

The need for sustainable development brought about sustainable entrepreneurship. However, it should be noted, that whether conventional, environmental, or social entrepreneurship the unique and common feature of any type of entrepreneurship is to make profit.

\section{REFERENCES}

[1] Ardichvili, A., Cardozo, R. \& Ray, S. 2003. A theory of entrepreneurial opportunity

[2] Identification and development. Journal of Business Venturing, 18,105-123. Available at: http://www.sciencedirect.com/science/article/pii/S0883902601000 684

[3] Belz, F. M., \& Binder, J. K. (2017). Sustainable entrepreneurship: A convergent process model. Business Strategy and the Environment, 26(1), 1-17.

[4] Bruyat, C., \& Julien, P. A. 2000). Defining the field of research in Entrepreneurship. Journal of Business venturing, 16, 165-180.

[5] Carsrud, A. L., \&Brannback, M. E. (2007). Entrepreneurship: Greenwood Publishing Group, Business \& Economics

[6] Cohen B., and Winn M. (2007). Market imperfections, opportunity and sustainable entrepreneurship. Journal of Business Venturing, 22(1), 29-49.

[7] Dimov, D. (2007). Beyond the Single-Person, Single- insight Attribution in understanding Entrepreneurial Opportunities, Entrepreneurship Theory and Practice 31(5), 713-731

[8] Elkington, J. (1997). Cannibals with Forks: The Triple Bottom Line of 21st Century Business. Capstone, Oxford, 1997, 402 pp. ISBN 1-900961-27-X.

[9] Emas, R. (2015). Brief for GSDR 2015 The Concept of Sustainable Development: Definition and Defining Principles, Florida International University

[10] Gast, J., Gundolf, K., \&Cesinger, B. (2017). Doing business in a green way: A systematic review of the ecological sustainability entrepreneurship literature and future research directions. Journal of Cleaner Production, 147, 44-56.

[11] Getzner, M., Grabner-Krauter, S. (2004). Consumer preferences and marketing strategies for "green shares". The International Journal of Bank Marketing, 22 (4), 260-278.

[12] Geverenova, T. (2015). Nature and Characteristics of green entrepreneurship. Trakia Journal of Sciences, 13(2), 321-323.

[13] Gatner, W, B. (1989). Who is an Entrepreneur? is the wrong Question. Entrepreneurship Theory and Practice, 13(4), 47-68.

[14] Gibbs, D. (2009). Sustainability Entrepreneurs, Ecopreneurs and the Development of a Sustainable Economy. Greener Management International, 55, 63-78.

[15] Greco, A. \& De Jong, G. (2017). Sustainable Entrepreneurship: Definitions, Themes and

[16] Research Gaps. Working Paper Series. Centre for Sustainable Entrepreneurship. University of Groningen/ Campus Fryslan.

[17] İyigün, N. Ö. (2015). What could Entrepreneurship do for Sustainable Development? A Corporate Social ResponsibilityBased Approach. Procedia-Social and Behavioral Sciences, 195, 1226-1231. https://doi.org/10.1016/j.sbspro.2015.06.253

[18] Kirzner, I., 1973. Competition and Entrepreneurship. University of Chicago Press, Chicago, IL.

[19] Kushwaha, R. (2010). Green marketing: Opportunity for Innovation and Sustainable Development; Jhunjhunwala Business School: Faizabad, India,

[20] Lenczuk From Corporate Greenwashing to Ecopreneurship: Sustainability as a Business Model

[21] Hannah KTH Royal Institute of Technology School of Computer Science and Communication

[22] Lotfi, M., Yousefi, A., \&Jafari, S. '(2018). The Effect of Emerging Green Entrepreneurship and Sustainable Development in Knowledge-Based Companies. Sustainability, 10. 2308
[23] Majid, I., Latif, A., \&Koe, W. (2017). SMEs intention towards sustainable Entrepreneurship. Journal of Multidisciplinary studies, 8385, 24-32.

[24] McMullen J. S., \& Shepherd, D. A. (2006). Entrepreneurial Action and the role of Uncertainty in the theory of the Entrepreneur. Academy of Management Review, 31(1), 132-152.

[25] Money U. \&Odibo E.E. (2015). Nigeria small and medium business management: An effect of entrepreneurship skills. Indian Journal of Commerce and Management studies,6(3), 31-36.

[26] Moshina V (2015). Does Entrepreneurship Contribute to Sustainable Development? ASystematic Literature Review Title of thesis Does Entrepreneurship Contribute to Sustainable Development? A Systematic Literature Review Department of Management Studies Aalto University School of Business

[27] Oluremi, H. A. \&Gbenga, M. A. (2011). Environmental factors and entrepreneurship development in Nigeria. Journal of Sustainable development in Africa, 166-176.

[28] Pacheco D. F., Dean T. J., \& Payne D, S. (2010). Escaping the green prison: Entrepreneurship and the creation of opportunities for sustainable development. Journal of business venture, 25, 464480

[29] Sarason, Y., Dean, T., \& Dillard J. F. (2006). Entrepreneurship as the Nexus of individual and Opportunity: A structuration View. Journal of Business Venturing, 21 (3), 286-305.

[30] Savitz A. W., \& Weber, K., (2006). The Triple Bottom Line. Jossey -Bass, San Francisco, CA.

[31] Schaper, M., 2002. The essence of ecopreneurship. Greener Management International, 38, 26-31.

[32] Schumpeter, J. A. (1934). Theory of Economic Development; Harvard University Press: Cambridge, MA, USA, 1934.

[33] Sendawula, K., Turyakira, P., \&Alioni, C. (2018). Sustainable entrepreneurship intention among university students in Uganda: A conceptual paper. African Journal of Business Management, 12(6), 131-139.

[34] Shane, S., (2004). A General Theory of Entrepreneurship: the Individual-opportunity Nexus. Edward Elgar, Northhampton

[35] Shane, S., \&Venkataraman, S. (2000). The promise of Entrepreneurship as a Field of Research. Academic of Management Review, 25(1). 217-226.

[36] Shepherd D. A., \&Patzelt, H. (2011). The new field of sustainable entrepreneurship: studying

[37] Entrepreneurial Action linking "What is to be sustained with what is to be developed". Entrepreneurship Theory and Practice, 36(3), 465-493.

[38] Standberg, B., \&Aarikka-Stenroos, L. (2014). What makes it so difficult? A systematic reviewon barriers to radical innovation. Industrial Marketing Management, 43(8), 1293-1305

[39] Udih, M., \& Emmanuel Odibo, E. (2016). The Impact of Entrepreneurship Growth in the Development of Nigerian Economy. Journal of Economics, Management and Trade, 15(4), 1-10. https://doi.org/10.9734/BJEMT/2016/27738

[40] UN Conference on the Human Environment (1972). Declaration of the United Nations Conference on Human Development, Stockholm, Sweden.

[4 1] United Nations Environment Programme (UNEP)., (2012).United Nations Environment TheBusiness Case for the Green Economy Sustainable Return on Investment

[42] Van de Ven, A. H. (1993). The Development of an Infrastructure for Entrepreneurship. Journal of Business Venturing, 19, 343-358.

[43] Venkataraman, S. (1997). The distinctive Domain of Entrepreneurship Research: An Editors Perspective. In Katz, Brockhaus R, Editors. Advances in Entrepreneurship, Firm Emergence and Growth. Greenwich, CT: JAI Press.

[44] World Commission on Environment and Development (1987). Our Common Future. Oxford University Press. Oxford, UK.

[45] Young, W., \& Tilley, F., 2006. Can businesses move beyond efficiency? The shift toward effectiveness and equity in the corporate sustainability debate. Business Strategy and the Environment, 15(6), 402-415. 